\title{
Simple tandem repeat DNA polymorphism in the human glycogen synthase gene is associated with NIDDM in Japanese subjects
}

\author{
H. Kuroyama, T. Sanke, S. Ohagi, M. Furuta, H. Furuta, K. Nanjo \\ The First Department of Medicine, Wakayama University of Medical Science, Wakayama, Japan
}

Summary We investigated the possible association between alleles of a simple tandem repeat DNA polymorphism in the human glycogen synthase gene and non-obese non-insulin-dependent diabetes (NIDDM) in Japanese subjects. Nine alleles $(-4 \mathrm{G},-3 \mathrm{G},-2 \mathrm{G}$, $-1 \mathrm{G}, 0 \mathrm{G}, 1 \mathrm{G}, 2 \mathrm{G}, 3 \mathrm{G}$, and $4 \mathrm{G}$ ) were identified in the study group of 164 patients with NIDDM and 115 nondiabetic subjects. The overall frequency distribution of the glycogen synthase gene alleles was significantly dif- ferent between the two groups $(p=0.0316)$. The $2 \mathrm{G}$ allele was found more frequently in patients with NIDDM than in non-diabetic subjects $(17.7 \%$ vs $8.7 \%$, $p=0.0016)$. These results suggest that the $2 \mathrm{G}$ allele could be a genetic marker of NIDDM in Japanese subjects. [Diabetologia (1994) 37: 536-539]

Key words NIDDM, glycogen synthase, DNA polymorphism, genetics, hypertension.
NIDDM is characterized by abnormal insulin secretion and insulin resistance, and is thought to be a multifactorial disorder [1]. Although some genetic abnormalities, such as mutations of insulin, insulin receptor and glucokinase gene, have been found in some types of diabetes, few data for candidate genes associated with NIDDM have been reported. Recently an association between an allele of XbaI RFLP of the glycogen synthase gene and NIDDM has been reported among a group of Finnish patients [2]. This DNA polymorphism ( $A_{2}$ allele) appeared to identify a subgroup of patients with NIDDM characterized by a strong family history of NIDDM, a high prevalence of hypertension, and marked insulin resistance. As glycogen synthase is a

Received: 13 November 1993

and in revised form: 3 January 1994

Corresponding author: Dr. T.Sanke, The First Department of Medicine, Wakayama University of Medical Science, 27 Nanaban-cho, Wakayama 640, Japan

Abbreviations: NIDDM, non-insulin-dependent diabetes mellitus; RFLP, restriction fragment length polymorphism; PCR, polymerase chain reaction key enzyme of the non-oxidative pathway of glucose metabolism, it seems likely that this enzyme is a candidate gene for contributing to the pathogenesis of NIDDM with marked insulin resistance. However, we could not find the XbaI RFLP ( $\mathrm{A}_{2}$ allele) in the glycogen synthase gene in 98 Japanese patients with NIDDM and 86 non-diabetic subjects by either Southern blot analysis [2] or PCR [3] (data not shown).

Recently, a simple tandem repeat DNA polymorphism (TG) $)_{\mathrm{n}}$ in the human glycogen synthase gene was identified [4]. Therefore, we investigated a possible association between this polymorphism and NIDDM in Japanese subjects.

\section{Subjects and methods}

\section{Subjects}

The study group consisted of 164 patients with NIDDM diagnosed according to WHO criteria and 115 non-diabetic subjects were studied. At blood sampling, informed consent was obtained from each individual according to a protocol approved by the Human Studies Committee. All subjects were unrelated Japanese and were residents of Wakayama and the south part of the Osaka prefectures. The non-diabetic subjects had no family history of diabetes and their fasting plasma glucose levels were 
all less than $6.1 \mathrm{mmol} / \mathrm{l}$ and $\mathrm{HbA}_{1 \mathrm{c}}$ less than $6.0 \%$. A positive family history was defined as diabetes diagnosed in grandparents, uncles, aunts, parents, or siblings. The diabetic patients in whom onset of the disease occurred before 40 years and the nondiabetic subjects under 40 years were excluded. All subjects had body mass index less than $30 \mathrm{~kg} / \mathrm{m}^{2}$. Hypertension was diagnosed according to WHO criteria, and those patients receiving treatment with anti-hypertensive drugs were also diagnosed as having hypertension.

\section{Methods}

Genomic DNA was extracted from peripheral blood leucocytes by the standard method. Two oligonucleotide primers (GS1: 5'-AGCTAATTTTTGTATCTGTG-3', and GS-2: 5'CCTGGGCATCAGAGCAAGAC-3') flanking the TG repeat in glycogen synthase gene were used to amplify a fragment made up of approximately 90 base pair as described by Vionnet and Bell [4] with slight modification. Genomic DNA was first digested by EcoRI and then ethanol precipitated before use in the PCR. The PCR was conducted in a volume of $25 \mu \mathrm{l}$ and included $150 \mathrm{ng}$ of the digested DNA, $30 \mathrm{pmol}$ of ${ }^{32} \mathrm{P}$-labelled GS-1 primer ( 5 pmol ${ }^{32} \mathrm{P}$-labelled and $25 \mathrm{pmol}$ unlabelled) and $6 \mathrm{pmol}$ of GS-2 primer. PCR conditions were initial denaturation at $94^{\circ} \mathrm{C}$ for $5 \mathrm{~min}$ followed by 35 cycles of denaturation at $94^{\circ} \mathrm{C}$ for $1 \mathrm{~min}$, annealing at $55^{\circ} \mathrm{C}$ for $1 \mathrm{~min}$ and extension at $72^{\circ} \mathrm{C}$ for $1 \mathrm{~min}$, and a final extension step for $10 \mathrm{~min}$. The PCR products were separated on an $8 \%$ polyacrylamide sequencing gel and visualized by autoradiography. DNA sequencing to confirm the number of TG repeats was done by dideoxynucleotide chain termination procedure after subcloning the amplified fragment into pGEM 3Z $(+)$.

\section{Statistical analysis}

Differences in the frequencies of the quantitative variables, such as age, body mass index, $\mathrm{HbA}_{1 \mathrm{c}}$ etc between the diabetic and non-diabetic groups were tested using unpaired, two-tailed Student's $t$-tests. The overall distribution of alleles was analysed by the $2 \times 7$ contingency tables after allele $-4 G, 3 G$ and $4 G$ had been combined because of the small size of these cells, and a $p$ value of less than 0.05 was considered significant. Individual allelic frequency differences were tested using $2 \times 2$ contingency tables for each allele by combining the remaining alleles into one category. The frequency differences between the two samples were tested using two-tailed Fisher exact tests, and a $p$-value of less than 0.007 was considered significant to correct for the number of comparisons made.

\section{Results}

The simple tandem (TG) repeat DNA polymorphism in the human glycogen synthase gene was highly polymorphic in Japanese subjects, and alleles $(-4 G,-3 G$, $-2 \mathrm{G},-1 \mathrm{G}, 0 \mathrm{G}, 1 \mathrm{G}, 2 \mathrm{G}, 3 \mathrm{G}$, and $4 \mathrm{G}$ ) were noted on typing 279 unrelated subjects (Fig. 1 and Table 1). The alleles varied in size from -8 to 8 base pairs with respect to $0 \mathrm{G}$ allele, respectively $(-8,-6,-4,-2,2,4,6$, 8 base pair). The nucleotide sequence of the amplified DNA fragment of OG/OG genotype revealed that it includes 18 repeats of TG dinucleotide and corresponded

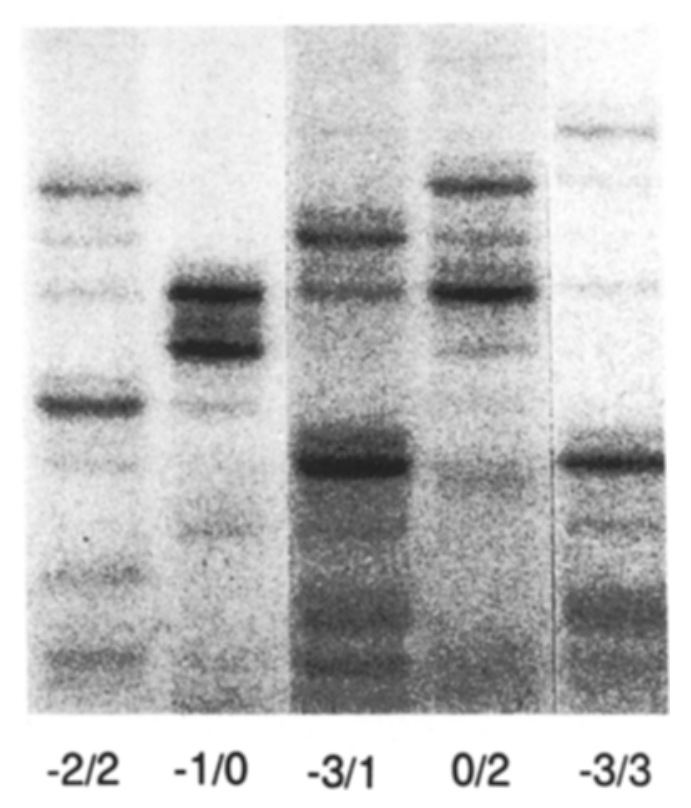

Fig.1. PCR amplification of simple tandem repeat DNA polymorphism in the glycogen synthase gene. The genotypes are shown at the bottom of the figure

to allele 7 of the report by Vionnet and Bell [4], but one base pair corresponding to the cytosine of 113 in their report was deleted in the downstream of the repeat.

Estimated allele frequencies are shown in Table 1. The overall frequency distribution of the alleles was significantly different between the diabetic and nondiabetic groups (chi-square $=13.83, d f=6$, two-sided $p$-value $=0.0316$ ). The $2 \mathrm{G}$ allele was found more frequently in diabetic patients than in non-diabetic subjects $(17.7$ vs $8.7 \%, p=0.0016)$. None of the nondiabetic subjects were homozygous for $2 \mathrm{G} / 2 \mathrm{G}$, while two diabetic patients had the $2 \mathrm{G} / 2 \mathrm{G}$ genotype. The frequencies of other alleles were not significantly different between the two groups. The diabetic patients were divided into two subgroups according to the presence or absence of the $2 \mathrm{G}$ allele. The clinical characteristics of each subgroup are compared in Table 1 . There were no significant differences between these two subgroups with regard to age, sex, body mass index, duration of diabetes and indices for metabolic control such as $\mathrm{HbA}_{1 \mathrm{c}}$ and fasting plasma glucose levels. The prevalence of need for insulin treatment was similar in the diabetic patients with the $2 \mathrm{G}$ allele and those without this allele. The daily doses of insulin were also not significantly different between the two subgroups. There was a tendency, but not significantly, towards a higher prevalence of positive family history of diabetes in the patients with the $2 \mathrm{G}$ allele compared to those without this allele (54.2 vs $41.7 \%, N S)$. In comparison with the prevalence of hypertension between the two subgroups, the diabetic patients who had persistent macroalbuminuria or elevated serum creatinine level (more than $1.1 \mathrm{mg} / \mathrm{dl}$ ) were excluded to avoid the influence of 
Table 1. Estimated allele frequencies at the glycogen synthase gene (upper panel) and clinical characteristics of diabetic patients with or without $2 \mathrm{G}$ allele (lower panel)

\begin{tabular}{|c|c|c|c|}
\hline & Diabetic patients & Non-diabetic subjects & Significance \\
\hline$n$ & 328 & 230 & \\
\hline \multicolumn{4}{|l|}{ allele marker } \\
\hline$-4 \mathrm{G}$ & $0.000(0)$ & $0.004(1)$ & NS \\
\hline$-3 G$ & $0.049(16)$ & $0.043(10)$ & NS \\
\hline$-2 \mathrm{G}$ & $0.024(8)$ & $0.048(11)$ & NS \\
\hline$-1 \mathrm{G}$ & $0.046(15)$ & $0.030(7)$ & NS \\
\hline $0 \mathrm{G}$ & $0.466(153)$ & $0.509(117)$ & NS \\
\hline $1 \mathrm{G}$ & $0.213(70)$ & $0.235(54)$ & NS \\
\hline $2 \mathrm{G}$ & $0.177(58)$ & $0.087(20)$ & $p=0.0016$ \\
\hline $3 G$ & $0.021(7)$ & $0.035(8)$ & NS \\
\hline \multirow[t]{2}{*}{$4 \mathrm{G}$} & $0.003(1)$ & $0.009(2)$ & NS \\
\hline & with $2 \mathrm{G}$ & without $2 \mathrm{G}$ & Significance \\
\hline$n$ & 55 & 109 & \\
\hline Age (years) & $59.8 \pm 10.8$ & $62.9 \pm 8.3$ & NS \\
\hline Sex (male/female) & $27 / 28$ & $54 / 55$ & NS \\
\hline Body mass index $\left(\mathrm{kg} / \mathrm{m}^{2}\right)$ & $22.9 \pm 3.3$ & $22.9 \pm 4.2$ & NS \\
\hline Positive family history of diabetes (\%) & 54.2 & 41.7 & NS \\
\hline $\mathrm{HbA}_{1 \mathrm{c}}(\%)$ & $8.1 \pm 1.5$ & $8.3 \pm 1.7$ & NS \\
\hline Fasting plasma glucose $(\mathrm{mmol} / \mathrm{l})$ & $8.32 \pm 2.46$ & $8.51 \pm 2.34$ & NS \\
\hline Non-insulin-treated patients (\%) & 67.3 & 67.9 & NS \\
\hline Insulin-treated patients (\%) & 32.7 & 32.1 & NS \\
\hline Daily insulin dose $\left(\mathrm{IU} \cdot \mathrm{kg}^{-1} \cdot\right.$ day $\left.^{-1}\right)$ & $0.346 \pm 0.164$ & $0.394 \pm 0.153$ & NS \\
\hline Prevalence of hypertension $(\%)^{a}$ & $34.0(17 / 50)$ & $50.0(49 / 98)$ & NS \\
\hline
\end{tabular}

Observed number of allele in samples at each locus given in parentheses in upper panel.

${ }^{a}$ Excluding the patients with renal dysfunction

renal dysfunction on blood pressure. The diabetic patients with the $2 \mathrm{G}$ allele tended to have a lower prevalence of hypertension than those without this allele ( 34.0 vs $50.0 \%$, NS). In addition, none of the 11 nondiabetic subjects with hypertension had the $2 \mathrm{G}$ allele.

\section{Discussion}

Several recent studies have demonstrated reduced insulin-stimulated glycogen synthase activity in skeletal muscle of patients with NIDDM $[5,6]$ and their firstdegree relatives [7]. Decreased levels of glycogen synthase mRNA in skeletal muscle of patients with NIDDM have also been reported $[8,9]$. These findings suggest that glycogen synthase is a possible candidate gene in the pathogenesis of NIDDM. In fact, it has been reported that an XbaI RFLP $\left(\mathrm{A}_{2}\right.$ allele $)$ in the glycogen synthase gene is positively associated with NIDDM in Finnish patients [2]. Subsequent studies have shown an association of the XbaI $A_{1}$ allele with NIDDM in French subjects [10]. However, there was no association between alleles of this XbaI RFLP in Japanese subjects [3]. Recently, another polymorphism in the human glycogen synthase gene, consisting of variable number of $a(T G)_{n}$ repeat, was identified [4]. Using this polymorphism, we showed that allele $2 \mathrm{G}$ is positively associated with non-obese NIDDM in Japanese subjects.
In a previous study by Groop et al. [2] using XbaI site polymorphism, the patient subgroup with the $\mathrm{A}_{2}$ allele had a strong family history of NIDDM, a high prevalence of hypertension and marked insulin resistance. In the present study using microsatellite polymorphism, the patient subgroup with the $2 \mathrm{G}$ allele tended to have a higher prevalence of positive family history of NIDDM, but this was not statistically significant. The prevalence of hypertension in the patient subgroup with the $2 \mathrm{G}$ allele was rather lower than those without it. We did not examine the degree of insulin resistance in the diabetic patients in detail using procedures such as the hyperinsulinaemic euglycaemic glucose clamp or the glucose minimal model. However, not only the prevalence of insulin-treated patients but also the daily insulin doses in these patients were not significantly different between the two subgroups of patients with or without the $2 \mathrm{G}$ allele. This suggests that the $2 \mathrm{G}$ allele does not correlate with insulin sensitivity, although further studies are required. These discrepancies between our findings and those of Groop et al. [2] may be due to ethnic differences in the genetic background for NIDDM or due to the two distinct polymorphic sites in the glycogen synthase gene.

Since glycogen synthase is a key enzyme of non-oxidative glucose metabolism, its mutation may contribute to insulin resistance. Studies are in progress to characterize the clinical features of subjects with $2 \mathrm{G} / 2 \mathrm{G}$ genotype and the glycogen synthase gene of these patients for mutations that may impair its function. 
Acknowledgements. The technical assistance of Ms. E. Miyaji is gratefully acknowledged. We thank Dr. G.I.Bell of Chicago University for his encouragement and support. This study was supported by a grant for diabetes research from Otsuka Pharmaceutical Co., Ltd., Japan.

\section{References}

1. Permutt MA (1991) Use of DNA polymorphisms for genetic analysis of non-insulin dependent diabetes mellitus. In: Harrison L, Tait B (eds) Genetics of diabetes part II. Baillere Tindall/Saunders, London, pp 495-526

2. Groop LC, Kankuri M, Schalin-Jantti C et al. (1993) Association between polymorphism of the glycogen synthase gene and non-insulin-dependent diabetes mellitus. N Engl J Med 328: 10-14

3. Kadowaki T, Kadowaki H, Yazaki Y (1993) Polymorphism of the glycogen synthase gene and non-insulin-dependent diabetes mellitus. N Engl J Med 328: 1568-1569

4. Vionnet N, Bell GI (1993) Identification of a simple tandem repeat DNA polymorphism in the human glycogen synthase gene and linkage to five markers on chromosome $19 \mathrm{q}$. Diabetes 42: 930-932
5. Thorburm AW, Gumbiner B, Bulacan F, Brechtel G, Henry RR (1991) Multiple defects in muscle glycogen synthase activity contribute to reduced glycogen synthesis in non-insulin dependent diabetes mellitus. J Clin Invest 87: 489-495

6. Vaag A, Henriksen JE, Beck-Nielsen H (1992) Decreased insulin activation of glycogen synthase in skeletal muscles in young nonobese Caucasian first-degree relatives of patients with non-insulin-dependent diabetes mellitus. J Clin Invest 89: 782-788

7. Schalin-Jantti C, Harkonen M, Groop LC (1992) Impaired activation of glycogen synthase in people at increased risk for developing NIDDM. Diabetes 41:598-604

8. Vestergaard H, Bjorbaek C, Andersen PH, Bak JF, Pedersen AO (1991) Impaired expression of glycogen synthase mRNA in skeletal muscle of NIDDM patients. Diabetes 40: 1740-1745

9. Vestergaard H, Lund S, Larsen FS, Bjerrum OJ, Pedersen O (1993) Glycogen synthase and phosphofructokinase protein and mRNA levels in skeletal muscle from insulin-resistant patients with non-insulin-dependent diabetes mellitus. J Clin Invest 91:2342-2350

10. Zouali H, Velho G, Froguel P (1993) Polymorphism of the glycogen synthase gene and non-insulin-dependent diabetes mellitus. N Engl J Med 328: 1568 